\title{
Dimensions of Sustainability
}

\author{
Wendell Cox and Jean-Claude Ziv \\ Conservatoire National des Arts et Metiers, Paris \\ $3^{\text {rd }}$ International SIIV Conference \\ Bari, Italy \\ September 22-24, 2005
}

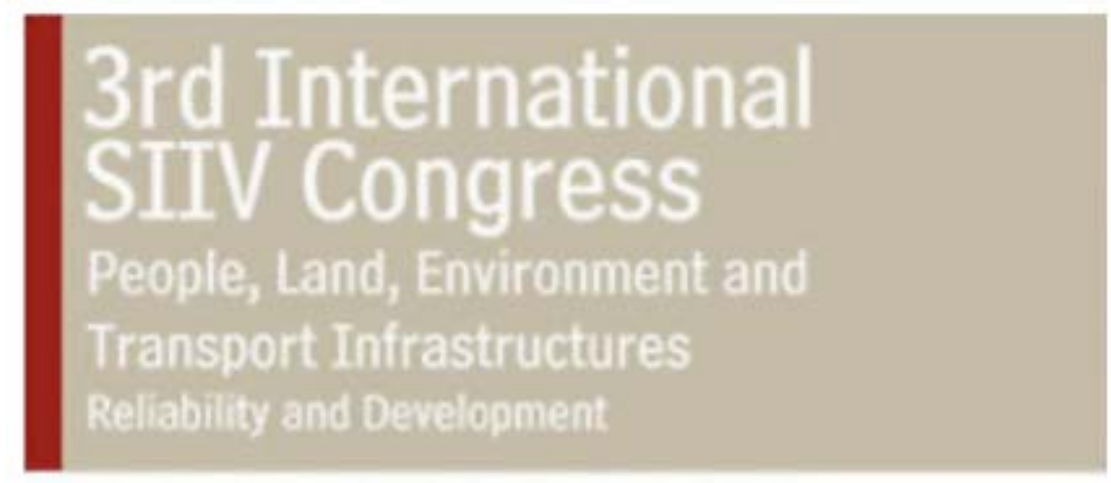

September 22-24, 2005 - Bari, Italy
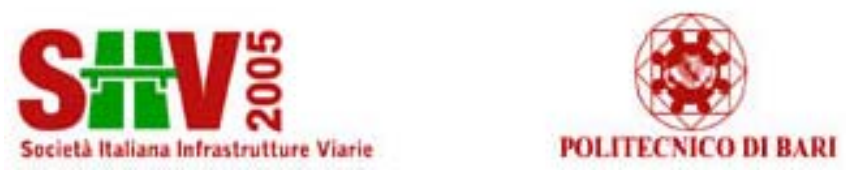

\begin{abstract}
Economic studies have shown that effective mobility and access improve incomes both for people and urban areas. At the same time, there is concern that the mechanisms of mobility be sustainable. But public and transport policies have been insufficiently broad in their characterization of sustainability. The principal focus of sustainability policy has been on environmental factors, which are, of course crucial.
\end{abstract}

But the actions of people and governments are often in conflict with policies adopted for environmental sustainability. As a result, environmental sustainability can, in some situations, be characterized as little more than a statement of intentions that is negated by the actions of people and government. This is principally because genuine sustainability must be acceptable. If policies intended to produce environmental sustainability are not observed by people and their governments, then their objectives cannot be met. Moreover, transport solutions that might be considered sustainable, but which cannot be affordably extended throughout an urban area may produce outcomes inferior to less expensive programs that might be extended throughout the area. 
Additional dimensions of sustainability are proposed that should be observed for the objectives of environmental sustainability to be achieved. These include issues such as public policy trends, preferences as revealed in household behavior, financial capability and infrastructure alternatives.

The purpose of the paper is to propose a public policy context for considering sustainability in the broader context. It is suggested that such an approach would lead, in the longer run, to more favorable economic and environmental results.

\section{WHAT IS SUSTAINABILITY?}

"Sustainability" is at the core of transport and land use policy around the world. Perhaps the most quoted definition was published in the "Brundtland Report" of the World Council on Environment and Development in 1987.

"Sustainable development meets the needs of the present without compromising the ability of future generations to meet their own needs."

This a broad definition effectively summarizes much of the philosophy of sustainability and will be used in this paper.

The interpretation of the Brundtland Report definition itself is open to considerable debate. The most fundamental difficulty is in defining "needs." What some people consider to be needs, others may consider simply to be merely desires and not needs. In daily life, the distinction between needs and desires can become blurred. People may pursue what most might consider to be desires just as ardently as if they were demonstrable needs. Thus, there could be much disagreement about what constitutes the needs "of the present" and needs "of the future."

Some might argue for a "needs of the future" interpretation that would seek the highest standards of living for the largest number of people, or the minimization of poverty (an objective that might not be achievable without the highest living standards). Others might argue for a much lower standard of living that could have as an ultimate objective the reduction of the highincome world quality of life to perhaps middle-income levels or even lower. Certainly, the former "needs of the future" interpretation would consume more resources than the latter, which, it might be argued, could compromise meeting the needs of future generations.

But this raises a further interpretive difficulty. What extent of resource consumption does the "future needs" standard require? Some might argue (and nearly do) that the very consumption of non-renewable energy, such as petroleum cannot be sustained and that, as a result, present consumption compromises the ability of future generations to meet their needs. Indeed, there are non-renewable resources. The consumption of one unit of such a resource leaves less for the future and indisputably reduces the availability of the resource for future generations. The extreme such position might be characterized as a form of "Malthusianism," which two centuries ago anticipated a future in which the world would not be able to feed itself --- at a time when the total world population was only one-sixth of the present level. This extremely conservative 
position, applied to sustainability, would require a massive reduction in consumption to ensure that future generations can meet their needs.

The opposite view is held by many who hold what might be called "Entreprenuerialism" --- the view that policies must take into consideration the ingenuity of humanity. They would note that the doom predicted by Malthus did occur because of advances in the agriculture and the sciences. For the entreprenuerialists, human ingenuity must be factored into public policy. The extreme position would suggest little concern with the needs of future generations, since human ingenuity can be counted upon to provide for future needs.

Obviously, truth lies between these two extreme views. With respect to some issues, there is a demonstrable imperative for strong regulation to ensure the needs of not only future generations but also of present generations. For example, water and air pollution, if not controlled, would not only compromise meeting the needs of future generations, but also the needs of those who live today. On the other had, there are issues about which there is not only not an immediate imperative, but there may not be one in the longer run. An example is petroleum consumption, a subject about which there is considerable current debate. The Entrepreneurialists would argue that to concentrate on the supply of petroleum is myopic and that human ingenuity will develop technological advances and alternative sources of energy that make it possible for present desires to be met without compromising the needs of future generations.

The comparatively recent history of air pollution and energy consumption provides an example. During the 1960s and 1970s, substantial concern arose with respect to the environmental and health effects of the urban air pollution produced by automobiles. In the 1970s, there were international oil shocks, which made greater energy efficiency a political imperative. It was assumed by many ${ }^{1}$ that addressing these two issues would require a massive shift of urban travel from automobiles to public transport. This what might be considered Malthusian view seemed reasonable, especially if the potential role of technological progress was not considered. But the progress was not the result of shifting demand from automobiles to public transport. It was virtually all technological, as human ingenuity responded to government regulation and public demands that air pollution be reduced and energy efficiency be improved. The automobiles of 2000 pollute far less than those of decades past, and they are more fuel efficient than in 1970.

All of this indicates that the issue of "sustainability" requires balance and reasonableness. If human ingenuity cannot be counted upon, then radical reversals in policy must be implemented. If human ingenuity is included in the equation, then a far less restrictive array of public policies is appropriate. The extent to which the most optimal public policies lean toward the Malthusian view or the Entreprenuerial view depends upon data and analysis, both of which are subject to considerable dispute.

The purpose of this paper is to outline issues of sustainability as they relate to urban transport and land use and to offer an assessment of current policy trends. Policy improvements are proposed.

\footnotetext{
${ }^{1}$ Including one of the authors, who was a member of the Los Angeles County Transportation Commission and chaired a Transportation Research Board national conference in Houston on energy contingency planning.
} 


\section{SUSTAINABILITY IN TRANSPORT}

In the past two decades, much in urban transport policy has been justified by interpretations of sustainability. A number of issues have been used to drive policies to favor the use of public transport and to discourage transport by automobile. Public transport is favored for a number of reasons, principally because of is purported environmental advantages. Public transport is generally thought to consume less energy per passenger kilometer, produce less air pollution and induce development that consumes less land. Thus, current urban transport policy in many areas seeks to attract drivers out of automobiles by making automobile use less convenient and more expensive, while making public transport improvements. Further, land use policies have been adopted in many urban areas that seek to make urban areas more compact (higher population densities) and to direct residential and employment locations such that commuting distances (work trips) are reduced. From the urban transport perspective, the purpose of these policies is to reduce private vehicle travel and to make the urban area more accessible by public transport.

\section{LAND USE POLICIES}

Over the last two centuries, population densities in the largest urban areas have declined precipitously. Transport has been a major factor in this. In 1800, the largest urban areas in the Western World, Paris and London, had estimated population densities of approximately 40,000 per square kilometer. At this time, the dominant form of urban transport was walking. Mass public transport did not arrive until somewhat later in the $19^{\text {th }}$ century. But, public transport itself worked to make large urban areas less dense.

By 1900, when there were few automobiles and public transport had a virtual monopoly on motorized transport, urban population densities had fallen to from 15,000 to 25,000 per square kilometer in the Western World’s largest urban areas (London, New York and Paris).

The automobile was to induce an even greater loss in urban population density. By 2000, the automobile had become the dominant form of motorized transport throughout the Western World. Population densities in the largest Western World urban areas had fallen to from 3,000 to 5,000 per square kilometer (New York, Los Angeles, Paris and London). Perhaps most surprising is that the Los Angeles urban area, which is often characterized as the model of "urban sprawl" is now more densely populated than the New York urban area, and only 30 percent less dense than the Paris urban area (Demographia, 2005a). Smaller urban areas have even lower densities, averaging under 1,500 per square kilometer in the United States, Canada and Australia and between 3,000 and 4,000 in Western Europe (Demographia, 2005b). Even in Japan, where automobile ownership rates have lagged far behind those of the Western World, urban population densities average less than 5,000. Often, pre-automobile densities will not be found even the large urban areas of the nations outside the high-income world, such as Mexico City, Sao Paulo, Buenos Aires (Demographia, 2005c). In recent decades, more than 90 percent of urban growth in high-income world metropolitan areas over 1,000,000 population has been outside the cores cities, in the suburbs (Demographia, 2004).

“Compact City" Policies: A strong view has arisen in public policy that the geographic expansion (pejoratively referred to as "urban sprawl”) of urban areas must be stopped or even 
reversed. This is principally based upon concerns that urbanization is materially reducing agricultural land and open space and on issues related to the automobile, such as energy consumption, traffic congestion and air pollution. A number of policies have been proposed under various titles, such as “compact city," “urban consolidation” and “smart growth.” Because nearly all urban expansion has been suburban, such policies can also be characterized as "antisuburban.” Generally, these policies would constrict the geographic expansion of urban areas through urban growth boundaries, green belts, and higher development charges, while seeking to limit roadway expansion and expand public transport.

Agriculture and Open Space: Urban geographic expansion has led to concerns that urban land consumption threatens the future, particularly with respect to agricultural production and the preservation of "open space." But a review of the data indicates that there remains considerable dispute with respect to the imperative for restricting the geographic expansion of urban areas.

According to the 2000 United States Census, only 2.6 percent of the nation's land area is urbanized. This leaves 97.4 percent that is either agricultural or open space. The United States Department of Agriculture has concluded that urbanization represents no threat to agriculture. There has been a decrease in agricultural land in the United States as suburbanization has been occurring since 1950, but greater productivity has led to large increases in output. In fact, in the United States, the "urban footprint” of agriculture and urbanization (“domesticated land”) has been reduced by an area larger than the states of Texas and West Virginia since $1950{ }^{2}$ This is at the same time that the urban population of the United States has increased 130 million, more than the population of France and Italy combined.

Available data indicates similar trends elsewhere. As urban development expanded widely in Japan, the urban footprint declined slightly from 1965 to 2000 (calculated from Japan Land Information Division, 2005). In Canada, urbanization uses approximately 96 percent less land than the nation's agriculture. Improving productivity has allowed agricultural land reductions since 1951 that are four times the total land used by urban areas in 2001. ${ }^{3}$ In Australia, urbanization uses less than 0.5 percent of the nation's land area. Improvements in agricultural productivity have permitted reduction of farmland by an area larger than the state of Victoria since $1980 .^{4}$

Moreover, the European Union, the United States, Canada and other high-income nations continue to subsidize agricultural production at substantial rates to keep prices high enough for farmers to earn sufficient returns on investment. If there were a serious threat to agricultural production, then there would be no need for agricultural subsidies, because market prices would provide sufficient returns.

Finally, population growth rates have fallen substantially in the high-income world and are headed downward in much of the rest of the world. World population projections have been significantly reduced in recent years. Thus, because there is less population growth, the demand for urban expansion will be less in the future.

\footnotetext{
${ }^{2}$ Calculated from US Bureau of the Census and US Department of Agriculture data.

${ }^{3}$ Calculated from Statistics Canada data.

${ }^{4}$ Calculated from Australian Bureau of Statistics data.
} 
Traffic Congestion: It is frequently implied that traffic congestion would be improved through compact city policies. This is based upon the assumption that higher densities would lead to greater public transport ridership and less automobile use. But, in fact, lower densities are associated with less intense traffic congestion. Peter Gordon and Harry Richardson of the University of Southern California make this point by noting that "suburbanization has turned out to be the traffic safety valve (Gordon and Richardson, 1998).

This is apparent from international data. The traffic intensity (vehicle kilometers per square kilometer) in the most dense urban areas was nearly three times as great as in the least dense areas in 1990. Average travel speeds were approximately one-half as fast. This means that there are considerably more vehicle hours of travel in the most dense urban areas, with values nearly six times those of the least dense urban areas (Table 1). ${ }^{5}$ This slower traffic, combined with the associated higher incidence of "stop and go" traffic means that air pollution emissions are more intense in local areas of the more dense urban areas. ${ }^{6}$

\begin{tabular}{|c|c|c|c|}
\hline \multicolumn{4}{|c|}{$\begin{array}{c}\text { Table } 1 \\
\text { Roadway Traffic Intensity by Population Density }\end{array}$} \\
\hline $\begin{array}{l}\text { Urban Density Range } \\
\text { (per square kilometer) }\end{array}$ & \begin{tabular}{|c|} 
Vehicle Kilometers \\
per Square \\
Kilometer
\end{tabular} & Average Speed & $\begin{array}{c}\text { Vehicle } \\
\text { Hours per } \\
\text { Square } \\
\text { Kilometer }\end{array}$ \\
\hline 15,000 \& Over & 90,260 & 25.2 & 3,587 \\
\hline $4,000-14,999$ & 78,647 & 29.8 & 2,643 \\
\hline $2,000-3,999$ & 60,927 & 39.0 & 1,563 \\
\hline $1,200-2,000$ & 45,419 & 48.4 & 938 \\
\hline Under 1,200 & 30,720 & 50.2 & 613 \\
\hline Average & 60,818 & 38.8 & 1,567 \\
\hline \multicolumn{4}{|c|}{ COMPARED TO LEAST DENSE CATEGORY } \\
\hline 15,000 \& Over & 2.9 & 0.5 & 5.9 \\
\hline $4,000-14,999$ & 2.6 & 0.6 & 4.3 \\
\hline $2,000-3,999$ & 2.0 & 0.8 & 2.6 \\
\hline $1,200-2,000$ & 1.5 & 1.0 & 1.5 \\
\hline Under 1,200 & 1.0 & 1.0 & 1.0 \\
\hline Average & 2.0 & 0.8 & 2.6 \\
\hline & & & \\
\hline
\end{tabular}

\footnotetext{
${ }^{5}$ Perhaps because the data is more easily accessible, measures of urban traffic congestion principally rely on distance measures, such as vehicle kilometers. But, it is arguable that travel time, expressed in vehicle hours, is a more important indicator. People seek to minimize their travel times, with distance being a secondary consideration. Thus, measures that seek to reduce gross travel distances, such as the Paris program of removing general purpose lanes from operation, have little potential value to consumers. If, for example, such measures reduce vehicle kilometers to some extent, they very likely also reduce travel speeds. It is thus possible that total vehicle hours could remain the same or even increase, along with air pollution emissions.

${ }^{6}$ This is the latest available data that includes both cars and trucks. This data includes some middle-income and lowincome urban areas, which tend to be far more dense. As automobile ownership continues to increase in these areas, it can be expected that traffic intensities will increase even further, unless urban densities fall substantially.
} 
The role of roadway freight often receives insufficient attention in analyses of traffic congestion. Roadway motor freight has been a major factor both in reducing product prices and improving the speed of goods delivery. If public policy pursues objectives that allow greater levels of traffic congestion, these advantages will be compromised or lost.

Acceptability: Further, there are serious questions about the political acceptability of antisuburban policy strategies proposed to minimize urban land usage.

One of the world's earlier and most aggressive programs for minimizing urban land use expansions has been implemented in Portland, Oregon. There, an urban growth boundary has been established, outside of which urban development is not permitted. Plans were adopted to require densification of neighborhoods, which was to have led to an approximately 50 percent increase in urban densities by 2040. But there was a strong public reaction against the densification policies, which culminated in a 2002 referendum in which a more than 60 percent majority voted to outlaw densification of existing neighborhoods. As a result, the urban growth boundary has now been expanded to include more territory than had been projected before the referendum for 2040.

Other negative public reactions to policies to contain urbanization have occurred in a number of other jurisdictions, such as in the Washington, DC area, and the state of New Jersey. The even more aggressive "urban consolidation" policies that have been adopted throughout Australia have produced protest movements in some urban areas, such as Sydney, Melbourne and Canberra. Changes in governments have led to policy reversals and dilutions in Minnesota and Maryland.

These negative reactions raise serious questions about the sustainability of anti-suburban policies themselves. In the cases of the US and Australian urban areas, population densities are particularly low. As a result, even apparently large percentage increases in density would leave the urban areas at well below the densities of the pre-automobile public transport oriented urban areas. For example, Portland's now abandoned 2040 urban density would have been only 2,000 per square kilometer, less than one-seventh that of pre-automobile London or New York. In fact, even if it had been possible for the Portland urban area to achieve its intended density, it would have remained 30 percent less dense than the Los Angeles urban area. Similarly, the proposed density increases in Australian urban areas would leave them far short of the public transport urban densities of the $19^{\text {th }}$ century.

Current Policy Directions: Modest Changes: In recent years, some urban cores have begun growing again, after years of decline. This has occurred in New York, London, Copenhagen, Stockholm, Tokyo, Chicago and other places. Yet these increases have been modest. London remains at least 1,000,000 people short of its estimated 1939 population peak, and projections currently indicate a population in 2021 that would exceed the 1939 peak by less than five percent. Whether or not this growth occurs, the part of Southeast England that, with London, represents the metropolitan area will contain most of the population and will continue to have a very low population density. At the 2021 projected population, London’s urban density would 
remain well less than one-half that of the pre-automobile past. Other core areas are generally not experiencing nearly the same rate of growth as in London.

The core density increases are most appropriately considered in micro rather than macro terms. The cores of many urban areas are becoming more attractive and more people are living there. But, in the context of the broader metropolitan area, the core density increases are doing little to change the urban form. From a transport perspective, it seems clear at this point that in the foreseeable future, all but a small part of urban areas will remain principally automobile oriented.

Despite the importance of centralization to compact city policies, most new urban job creation has been and continues to occur outside the urban core, in the suburbs. ${ }^{7}$ This is evident, for example, in central Paris, where the number of jobs declined 18 percent from 1,087,000 to 891,000 between 1990 and $1999 .^{8}$ The largest central business districts in the high-income world, including Tokyo, Osaka ${ }^{9}$ and New York are either experiencing no growth or declining in their employment levels. Central London, which has begun to grow since the middle 1990s, is an exception.

Thomas Sieverts of the University of Darmstadt has characterized the political difficulty of material urban density increases by noting that the "compact city" can only be obtained through processes that are not democratic (Sieverts, 2003).

And, perhaps in recognition of political practicalities, few advocates of anti-suburban policies propose densification programs that would return today's automobile oriented urban areas to densities that rival those of the pre-automobile era. For example, a seminal study by Robert Burchell et al (Burchell, 2002) argued strongly for the development of more compact urban areas in the United States. Yet, the more compact designs assumed in the study would have only reduced the projected 2025 urban use of land from 3.5 percent to 3.3 percent.

Much more would be required to fundamentally transform the urban area from automobile to public transport orientation than the modest policy strategies proposed by current urban planning. Today's public transport systems principally serve the dense urban cores and provide little connectivity between within the suburbs, where most people live and where most of the employment is to be found. For most trips in the modern Western urban area, public transport is not competitive with the automobile. The very geographical size of modern urban areas makes it virtually impossible for public transport to compete for the larger share of urban transport. This is because as the urban area becomes larger geographically, there is a geometric increase in potential origin and destination pairs. This makes it cost prohibitive to provide public transport service throughout the urban area that is competitive with the automobile (Cox, 2002). Moreover, it is possible that even in the more compact, public transport urban areas of the past that mobility was not competitive with the levels now made possible by automobile availability.

\footnotetext{
${ }^{7}$ Detailed information at http://www.demographia.com/db-intlcbd-trend.htm.

${ }^{8}$ Calculated from INSEE data (http://www.demographia.com/db-paris-empl.htm).

${ }^{9}$ Calculated from Japan Statistics Bureau data, http://www.demographia.com/db-tokcbd.htm and http://www.demographia.com/db-osakacbd.htm).
} 
Assessment: In short, it is arguable that urban expansion in its present form is sustainable and does not represent a threat to the needs of future generations. There is virtually no reason to believe that the urban area of the foreseeable future will be materially less automobile oriented than today. Moreover, the modest proposals to reduce urban expansion are themselves evidence that not even the critics are sufficiently concerned to propose land use strategies draconian enough to drive material amounts of automobile demand to public transport. The anti-automobile policies that pervade so much of current urban planning would, even if successfully implemented, result in an urban area little less automobile oriented than today.

\section{TRANSPORT}

Sustainable urban transport policies tend to favor public transport use and discourage automobile use. But, as in the case of land use policy, there are difficulties with the conventional view. The purported superiority of public transport over the automobile is not without question. But more importantly, there are serious practical limits with respect to the potential for public transport to substitute for automobile use.

Public Transport Market Trends: The first concern is that, despite strong public policy initiatives, little, if any, progress has been made in attracting drivers from automobiles to public transport. Historically, as automobile ownership has expanded, the share of travel on public transport has dropped materially. While 100 percent of motorized travel was by public transport little more than 100 years ago, today more than 80 percent of surface travel is by car in Western Europe, while urban transport market shares have fallen below 10 percent in Canada and Australia and below five percent in the United States (below two percent if school buses are excluded).

In the European Community, automobile market shares continue to rise. Between 1990 and 2001, the share of surface passenger travel by automobile rose slightly, from 83 percent to 84 percent, with a corresponding loss in public transport's urban and intercity share (Calculated from European Commission Directorate- General, 2003). Public transport market shares throughout the world have also continued to decline. An analysis of more than 40 international urban areas indicated an average public transport loss of 13 percent per decade since 1980 (Public Purpose, 2004). Losses were sustained in more than 80 percent of urban areas, while no gains of more than 10 percent occurred. Even in Singapore, where there are strong policies to discourage both automobile use and ownership, From 1980 to 2000, the automobile work trip market share increased by three-quarters. ${ }^{10}$ What are characterized as "sustainable" urban transport policies have failed to produce the intended transformation. Moreover, there is little reason to believe that "sustainable" public transport policies will be materially more effective in the future. Generally, long term urban transport plans foresee a future of automobile domination, with little demand switched to public transport.

Public Transport: Not a Substitute for the Automobile: As has been noted above, public transport is not competitive with the automobile for most urban trips. As a result, outside core areas, the automobile is strongly dominant. In the United States, little travel outside the urban cores is by public transport. People who travel by public transport to non-core work locations

${ }^{10}$ Calculated from Singapore Land Transport data. See http://www.publicpurpose.com/ut-sng-jtw.htm. 
tend to have household income levels more than 40 percent below average, while public transport commuters to core areas have incomes within 10 percent of average, ${ }^{11}$ which would seem to indicate that such commuters have a lower rate of automobile availability.

Even where the most effective systems are available, public transport tends to fall far short of providing the mobility of the automobile. In the Paris area, for example, new towns have been established along the RER suburban rail system, surely one of the most comprehensive such systems in the world. Yet, Fouchier and Michelon have shown that, on average, a 60 minute travel time on public transport can access less than one-half of the jobs that can be reached by the automobile (Table 2). Approximately 84 percent of jobs in the metropolitan area can be reached by automobile within 60 minutes, while only 40 percent can be reached by public transport. It seems likely that the advantage of the automobile may be even greater in the many Paris suburbs that are not directly served by RER.

${ }^{11}$ Calculated from 1990 US Census data. See http://www.publicpurpose.com/ut-25cbd\$.htm. 


\begin{tabular}{|l|r|r|r|}
\hline \multicolumn{3}{|c|}{ Table 2 } \\
Paris New Towns: Automobile and Public Transport Labor Markets \\
\hline New Town & $\begin{array}{c}\text { Automobile } \\
\text { Labor Market }\end{array}$ & $\begin{array}{c}\text { Public } \\
\text { Transport } \\
\text { Labor Market }\end{array}$ & $\begin{array}{c}\text { Public } \\
\text { Transport } \\
\text { Compared to } \\
\text { Automobile }\end{array}$ \\
\hline Lieusaint Moissy & $87 \%$ & $26 \%$ & 0.30 \\
\hline Evry & $86 \%$ & $36 \%$ & 0.42 \\
\hline Cergy & $73 \%$ & $45 \%$ & 0.62 \\
\hline Saint Quentin en Yvelines & $78 \%$ & $49 \%$ & 0.63 \\
\hline Noisiel (Marnes) & $94 \%$ & $48 \%$ & 0.51 \\
\hline Average & $84 \%$ & $41 \%$ & 0.49 \\
\hline $\begin{array}{l}\text { Employment Accessibility within } 60 \text { Minutes } \\
\text { Calculated from Fouchier.and Michelon, 1999. }\end{array}$ \\
\hline
\end{tabular}

Public Transport Sustainability: There are also serious questions about the sustainability of public transport itself, such as those raised by Remy Prud'homme, et al with respect to Western Europe (Prud'homme at al, 1999). Perhaps this is most obvious in the United States, where public transport funding has increased substantially, at the same time that there has been little change in ridership and a substantial loss in market share (Figure 1). From 1970 to 2002, annual spending on public transport rose more than 230 percent (inflation adjusted), ridership increased 11 percent and public transport's urban market share fell 51 percent. $^{12}$

\footnotetext{
${ }^{12}$ Estimated from US Department of Transportation Federal Transit Administration and American Public Transportation Association data.
} 


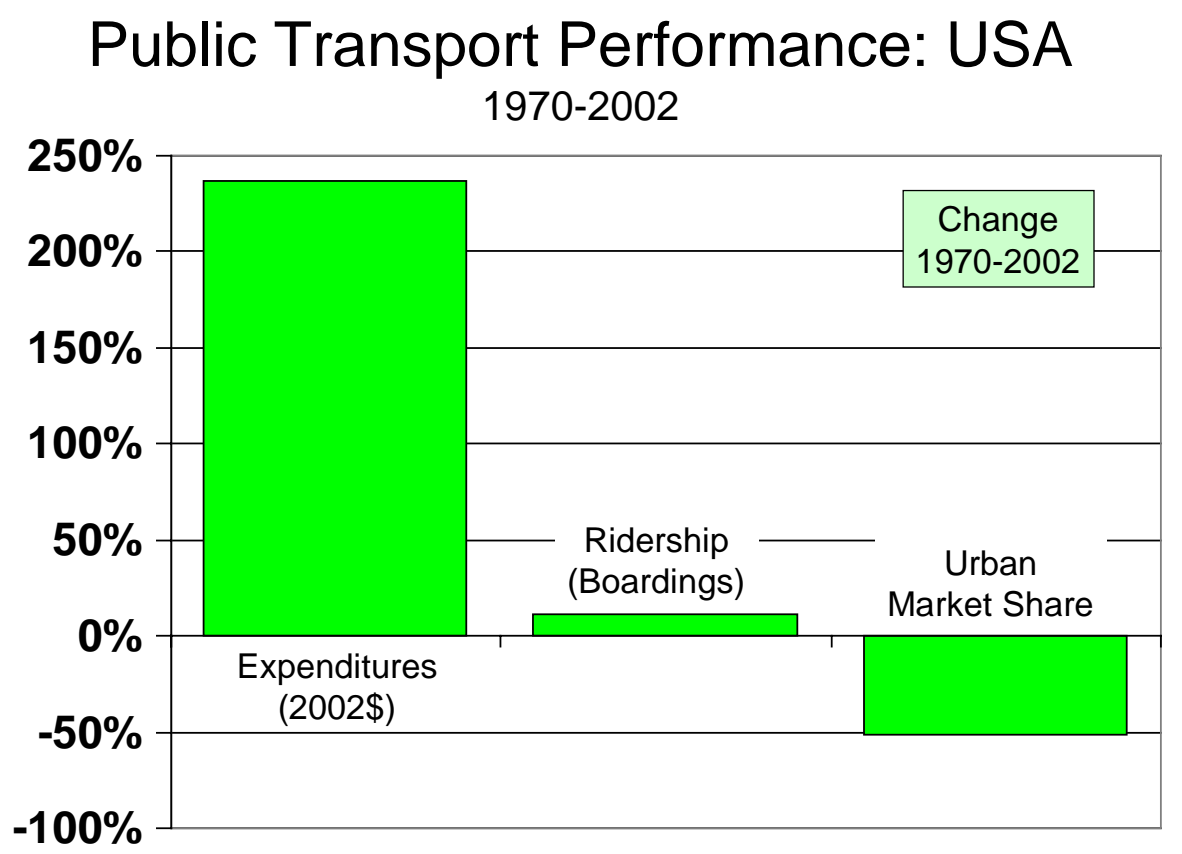

Figure 1

In the US, the failure of new funding to produce benefits corresponding to the increase in expenditures is due to the avoidance of cost saving incentives, such as competitive tendering and privatization. But perhaps an even more substantial influence has been the unnecessarily high cost of new public transport infrastructure. Urban areas with overwhelmingly slow and ineffective public transport systems have typically sought and obtained funding from the federal government to build expensive new rail lines. In most cases, only one or two new rail lines have been built. The far more comprehensive rail systems that might lead to a slightly decreased automobile market share have simply not been affordable. In nearly all cases, the new urban rail lines have been inordinately costly in relation to their contribution.

For example, the US Federal Transit Administration's 2000 New Starts report reported a cost per new passenger for the new light rail line in Minneapolis-St. Paul equal to more than $\$ 8,000$ for each commuter who uses the system twice each workday (Table 3). If the same amount were spent on all trips nearly the gross annual personal income of the Minneapolis-St. Paul metropolitan area (one of the world's affluent ${ }^{13}$ ) would be required. Obviously, sufficient levels of public transport cannot be afforded at such rates to materially reduce automobile market shares. By spending more than necessary on a single public transport rail line, meeting both the present and future needs of other people in the metropolitan area are compromised.

\footnotetext{
${ }^{13}$ For additional details see http://www.demographia.com/db-intlgdp-metro.htm.
} 


\begin{tabular}{|c|c|}
\hline \multicolumn{2}{|c|}{$\begin{array}{c}\text { Table } 3 \\
\text { Example of Unsustainable Urban Transport Investment } \\
\text { Minneapolis-St. Paul: Hiawatha Light Rail Line }\end{array}$} \\
\hline Cost per New Ride & $\$ 18.53$ \\
\hline Annual Commuter Cost (450 Trips) & $\$ 8,339$ \\
\hline Annual Cost Applied to All Trips in the Metropolitan Area & $\$ 103,416,000,000$ \\
\hline Exhibit: Gross Personal Income of the Metropolitan Area & $\$ 117,552,000,000$ \\
\hline
\end{tabular}

Similar examples can be cited from throughout the United States. It is likely that similar calculations would be less stark in Western Europe, but still substantial. For example, Gerondeau finds that regional rail costs in France can be greater than those of taxis (Gerondeau, 2004). In fact, contrary to their rhetoric, today's public transport favoring public policies do not genuinely favor public transport, because they invariably produce a considerably less than optimal return on funding expended. But there are models that can be used to improve the return on public transport expenditures, such as the competitive tendering programs implemented in Stockholm and London and the low cost rapid bus improvements implemented in Curitiba, Porto Alegre, Bogota and Los Angeles.

Jobs-Housing Balance: Improving the balance between the geographical placement of jobs and housing is an often cited goal of sustainability policies. The claim is that modern land use and automobile commuting patterns result in longer than necessary work trips that are inordinately time consuming. The answer is to design self-contained communities in which there is a greater balance between jobs and housing, in what have been characterized as "urban villages."

But the reality has been far from successful. Urbanologist Peter Hall finds that in Stockholm's satellite communities, built with similar intentions, the overwhelming majority of people work elsewhere (Hall, 1998). In 2001, the average work trip travel distance in London area new towns, ${ }^{14}$ which were to have been self-contained, was approximately double their idealized diameter. ${ }^{15}$ This means that the average work trip length is longer than traveling completely across the new town and that the objective of self containment --- the jobs housing balance in which new town residents work locally, has not been achieved.

London (the area of the Greater London Authority) itself has been cited as an example for this "urban village" approach to urbanism. Here, there are a multiplicity of community high streets that can give the impression that GLA is a collection of urban villages. And, while an argument may be made in favor of a shopping-jobs balance, the data suggests the opposite with respect to jobs. These urban villages are far from self contained. The average work trip distance in 2001 in the London boroughs was approximately 10 kilometers. In the GLA boroughs, the average work

\footnotetext{
${ }^{14}$ All are outside the London urban area and the green belt.

${ }^{15}$ Calculated from Office of National Statistics data, see http://www.demographia.com/db-seuknewtowns.htm.
} 
trip was 1.6 times the borough diameter (The actual neighborhood or urban village diameters would be smaller). ${ }^{16}$

In the United States, surveys by the Bureau of the Census indicate that considerations other than work location represent the principal reason for neighborhood choice among less than onequarter of households who move. ${ }^{17}$ Overall, only 23 percent of moving households cited proximity to employment as the main reason for their choice of a new neighborhood. Among those purchasing their homes, which represent nearly 70 percent of households, the figure was even less, at 14 percent.

There are fundamental difficulties with the concept of establishing self-contained urban villages in urban areas. As the US Census Bureau data indicates, the planning desire to minimize work to job commuting differences is not shared by the majority of households. There may be more than one worker in the household, which makes commute distance minimization more difficult. It is simply not feasible to provide for a sufficient array of jobs that meet the needs of neighborhood residents and employers. At any point, a worker who lives nearby may accept a more remote job for better pay or conditions and choose not to move closer to the new job.

The most fundamental difficulty with urban villages and the jobs-housing balance is that the very reason that urban areas became large was because they developed as large labor markets in which people could work in the local neighborhood or many kilometers away. To transform the urban area into a series of urban villages would undermine the very purpose of the modern urban area. In fact there is a jobs-housing balance and it is at the labor market level - the urban area level. The fences that urban planners would like to build have been and will continue to be ignored by people who tend to do what they want more than what the planners want.

Energy Consumption: Certainly, at least in theory, public transport is more energy efficient than the automobile. This can be demonstrated by any calculation of the vehicle kilometers consumption per liter that are achieved by public transport vehicles operating at capacity compared to with average automobile occupancy. But the problem is that public transport vehicles do not always operate at capacity. In fact, they operate so far below capacity that, at least in the United States, there is little difference between the fuel efficiency of public transport and automobiles. Automobiles themselves are little more than two percent less fuel efficient than public transport and if SUVs (sport utility vehicles and pickup trucks) are included, public transport's advantage is less than 10 percent (Table 4). US Federal Highway Administration data indicates that automobile fuel efficiency has increased approximately 50 percent since 1970.

\footnotetext{
${ }^{16}$ Calculated from Office of National Statistics data, see http://www.demographia.com/db-lonborcommute.htm.

${ }^{17}$ Calculated from U.S. Bureau of the Census data. See http://www.demographia.com/db-usajhb2001.htm.
} 


\begin{tabular}{|l|r|r|r|}
\hline \multicolumn{3}{|c|}{ Table 4 } \\
\hline & $\begin{array}{l}\text { Passenger } \\
\text { Kilometers }\end{array}$ & \multicolumn{1}{|c|}{ BTUs } & $\begin{array}{r}\text { BTU/Passeng } \\
\text { er Kilometers }\end{array}$ \\
\hline Personal Vehicles & & & 2,225 \\
\hline Automobile & 4.101 & 9,124 & 2,519 \\
\hline Personal Truck (SUV) & 1.881 & 4,737 & 2,317 \\
\hline Total & 5.981 & 13,861 & \\
\hline & & & 2,558 \\
\hline Public Transport & & & 1,932 \\
\hline Bus & 0.036 & 92 & 1,690 \\
\hline Urban Rail & 0.025 & 49 & 2,177 \\
\hline Commuter Rail & 0.015 & 26 & \\
\hline Total & 0.076 & 166 & \\
\hline \multicolumn{3}{|c|}{} & \\
\hline $\begin{array}{l}\text { In Trillions of Passenger Kilometers and British Thermal Units } \\
\text { Source: Table 2.11 USDOE Transportation Energy Book 2001 }\end{array}$ \\
\hline
\end{tabular}

In nations with higher public transport vehicle capacity utilization, more favorable comparisons to the automobile would be expected. But even such findings would need to be tempered by the reality that, for most urban trips, public transport is not competitive with the automobile. Thus, while public transport is likely to be more energy efficient where demand justifies high levels of service, in the broader more populous suburbs outside the urban cores, services may be less energy efficient or not even available. The reality is that, given the present urban form, which even the most aggressive compact cities policies will not change materially (above), public transport is not an energy efficient alternative to personal vehicles because it cannot substitute for a meaningfully greater share of urban travel.

There are also concerns about the sustainability of the present dominant fuel source, petroleum. This is a subject of considerable dispute. But it seems clear that higher petroleum prices will lead to greater entrepreneurship, putting into production sources of supply that were not previously economic. For example, exploitation of the vast shale oil deposits of the US Mountain West might begin again along with the tar sand deposits of Alberta.

But that dispute may be irrelevant. Automobile fuel efficiency has improved markedly and future gains appear to be on the horizon. For example, the petroleum-electric hybrid cars now being marketed throughout the high-income world hold the potential to substantially improve fuel efficiency. If petroleum prices were to rise substantially from present levels, people might begin to buy smaller, lighter cars, thus retaining present levels of mobility while consuming less fuel. In addition, fuel-cell powered automobiles could well be on the horizon, which would use hydrogen fuel, rather than petroleum.

Air Pollution: There is rightful concern about the air pollution impacts of automobiles. In fact, public policies throughout the high-income world have sought to reduce automobile air pollution for decades, largely through improved vehicle emission technology. As a result, automobile air pollution appears to be a problem well on the way to being solved. In the United States, for 
example, the Environmental Protection Agency reports that gross air pollution emissions have declined 48 percent, or more than 60 percent per capita, since 1970. According to Joel Schwartz, air pollution from motor vehicles will fall even further, with a decline of 80 percent over the next 20 years, after taking into account increased driving that is likely to occur over the period. The experience has been similar in Europe.

Carbon Dioxide: There is also concern about the amount of carbon dioxide emitted by automobiles. But, as in the case of energy consumption, there are reasons to expect that substantial gains from human ingenuity and technology. Continued improvements in automotive energy efficiency (above) promise to reduce the rate of future carbon dioxide emissions. Moreover, there are already indications that presently available technologies could be used to materially reduce carbon dioxide emissions (Bedsworth, 2004).

Assessment: The analysis above would seem to indicate that land use and urban transport policies adopted to achieve sustainability have had comparatively little impact. Urban areas continue to expand geographically and certainly show no signs of returning to the much higher densities that would be required to materially alter urban travel patterns. Public transport itself has continued to experience market share declines and shows no signs of making substantial inroads into automobile market shares. The policies of sustainability seem unlikely to achieve their goals and may be themselves unsustainable.

\section{ADDITIONAL DIMENSIONS OF SUSTAINABILITY}

Part of the problem may be that policies adopted in the name of sustainability have excluded important dimensions. The most obvious would appear to be acceptability and economics.

\section{ACCEPTABILITY}

It would seem that a minimum criteria of sustainability would be acceptability --- that people would be inclined to behave in manners that advance the policy agenda. What is not acceptable cannot, by definition, be sustainable. A principal failing of sustainability policy has been that it has taken human nature insufficiently into consideration. Publication of plans and dictates do not change the desires of people. And, whether or not it is appreciated by planners, people often tend to equate desires with needs. It might be intellectually argued, for example, that people can get along without a car or live in a high-rise building without a garden. But if people desire living where they need cars to access employment and shopping and want suburban housing with gardens, then policies that seek to impose other lifestyles are not likely to be successful. Planning policies can prohibit people from doing living or working in particular locations, but such policies cannot successfully dictate where they must live or work, at least in a democratic society.

If policies are consistent with the desires of the populace, they are likely to produce distortions that may produce even more negative results than if the policies had never been adopted. For example, compact city policies in the San Francisco Bay area appear to have driven most population growth to exurban communities well beyond the urban area. The result is longer automobile commutes and lower public transport market shares. 
Thus, genuine sustainability policy must be acceptable.

\section{ECONOMICS}

The economic history of humanity is one of poverty. This is illustrated by an examination of gross domestic product data developed by Angus Maddison of the Organization of Economic Cooperation and Development (Maddison, 2003). Based upon the 2000 United States poverty threshold (per capita), the United States, Australia and New Zealand had only slightly above poverty incomes (inflation adjusted). On the eve of World War II, Western Europe's average income was only 14 percent above the US 2000 poverty rate, while Japan's was nearly 40 percent below the poverty threshold. By 2000, each of these nations had become far more affluent, with incomes ranging from five to seven times the 2000 US poverty threshold.

The unprecedented period of prosperity since World War II has been an era of unprecedented urban geographic expansion, while automobile ownership has risen strongly. It is not unreasonable to believe that there may be a connection between modern land use patterns, automobile ownership and affluence.

Mobility and Economic Growth: It is generally accepted that greater mobility translates into greater employment opportunity and higher incomes. For example, Prud'homme and Lee found that the number of jobs accessible within a fixed time (labor market) increases, there is a 1.18 productivity improvement factor (Prud'homme and Lee, 1998).

Home Ownership and Economic Growth: An important contributor to the expansion of wealth since World War II is home ownership. In at least Western Europe, Canada, Australia and the United States, home ownership rates have increased. Home equity has generated a rise in household assets compared to what would have occurred if rental rates had remained higher. The US Federal Reserve Bank estimates that approximately one-half of middle-income wealth is in home equity. ${ }^{18}$

The relationship between home ownership, wealth creation and economic growth has been given little attention in the literature of land use and transport sustainability. It is a well established fact of economics that scarcity tends to drive prices higher. As land use policies have placed substantially greater limits on land that can be developed for residential and commercial uses, prices have been forced upward. For example:

In the United Kingdom, the Barker Report, commissioned by the Deputy Prime Minister, has blamed restrictive land use policies for the inordinate rise in British house prices relative to the nations in continental Europe (Barker, 2004).

\footnotetext{
${ }^{18}$ Heritage Foundation Center for Data Analysis calculations from U.S. Federal Reserve Board, Survey of Consumer Finance, 1998 as cited in Wendell Cox and Ronald D. Utt, Smart Growth, Housing Costs and Home Ownership, Washington: Heritage Foundation, April 6, 2001.
} 
In the United States, the federal Department of Housing and Urban Development cites misuse of land use restrictions as a principal cause of declining housing affordability (United States Department of Housing and Urban Development, 2005).

Edward Glaeser and Joseph Gyourko have published research concluding that a principal cause of housing affordability differences between United States metropolitan areas is restrictive land use controls (Glaeser and Gyourko 2002).

Over the past 30 years, US states with significant land use restrictions have experienced the greatest decline in housing affordability ${ }^{19}$

Most of the least affordable housing markets in the United States, Canada, Australia and New Zealand have adopted compact city policies (Demographia 2005d).

Proponents of compact city policies have produced reports attempting to demonstrate that such policies do not lead to lower levels of housing affordability. But perhaps the most influential such study, published by the Brookings Institution (Nelson, Pendall, Dawkins and Knaap, 2002), concedes that if compact city policies produce scarcity, they will lead to lower levels of housing affordability.

Other analysts have suggested that recent housing affordability losses are the result of low interest rates or strong population growth. But, in fact, three of the fastest growing large urban areas in the high-income world (Dallas-Fort Worth, Houston and Atlanta) have managed to retain housing affordability rates that are average or better, despite experiencing low interest rates as in Portland, Sydney, Vancouver and London, where housing affordability has been seriously retarded.

Suffice it to say that, given the important role of home ownership in wealth creation, any policy that diminishes home ownership is likely to have negative economic impacts. Economic sustainability must be added to the policy equation.

Another “Tale of Two Cities:” Other evidence can be found in comparing two nearby large urban areas that have had materially different land use and transport policies. Since World War II, the London area has been subject to strict land use policies that included development of a wide greenbelt that has forced all growth to the outside. The London area is relatively poorly served by highways, with most motorway length in the single M-25 ring road. In contrast, contiguous urbanization has been permitted in the Paris area, which has also built the greater portion of three motorway standard ring roads, as well as wide motorways that connect them. Despite the strong financial core of London, data indicates that the Paris area is substantially more productive than the London area. A report commissioned by the Corporation of London found that major contributing factors were the better urban transport system of Paris, including both public transport and highways (Center for Economics and Business Research, Ltd and Observatoire de l'Economie et des Instiutuions Locales, 1997). It also found that effective labor markets were substantially larger in Paris than in London. For example, 60-minute labor markets in the Paris area average at least one-quarter more employment than in the London area. This is

${ }^{19}$ Calculated from US Census data. See http://www.demographia.com/db-usafford1970.htm. 
despite transport systems that exhibit similar speeds. ${ }^{20}$ The discontinuous development that has been imposed upon the London area through the green belt appears to have imposed a cost in terms of labor market efficiency. If contiguous development had been permitted to occur, labor markets would be larger in London. ${ }^{21}$

It is generally accepted that greater mobility translates into greater employment opportunity and higher incomes. For example, Prud'homme and Lee found that the number of jobs accessible within a fixed time (labor market) increases, there is a 1.18 productivity improvement factor (Prud'homme and Lee, 1998.

\section{TRANSPORT INVESTMENTS}

As noted above, extravagant investment policies can, in themselves, be unsustainable. The Boston area cannot afford to provide the same high level of mobility throughout the metropolitan region that is provided by the $\$ 15$ billion Central Artery highway project. Similarly not even the richest urban areas in the world (Minneapolis-St. Paul, for example) can afford to provide the level of urban rail service throughout the entire urban area. Most of the community can never hope to have urban rail service that serves its travel origins and destinations similar to the Hiawatha line that has been extravagantly imposed on a single core oriented corridor.

The result all too common projects such as these is to advantage a small part of the community, at great expense, at the same time that the much greater community receives little of no benefit, and can hope in the future to receive no such benefit due to the excessive costs. Greater mobility benefits could have been achieved throughout the area with less expensive strategies aimed at the greatest overall improvement for the funding available.

For public transport to have any hope of maintaining, much less improving its comparatively small urban market shares in Western Europe, North America and Australasia will require that it spend its funding to the greatest effect. Overall, there is a need to apply objective criteria to transport investments. For example, the potential for reducing traffic congestion could be improved by applying a standard of cost per roadway delay hour reduced to both roadway and public transport project evaluation.

\section{ADDITIONAL DIMENSIONS OF SUSTAINABILITY}

Thus, it is proposed that urban planning and transport planning would achieve more favorable results if at least the following dimensions of sustainability were added:

\footnotetext{
${ }^{20}$ To have equaled the size of Paris labor markets with its green belt, London could have compensated with huge highway investments, which would have made it possible for drivers to travel further in the same period of time. Generally more robust roadway systems, combined with the lower traffic intensity from lower population density, has allowed more geographically expansive urban areas in the United States to retain some of the best work trip travel times in the high-income world and correspondingly large labor markets. For example, see: http://www.publicpurpose.com/ut-intljtwtimesize.htm.

${ }^{21}$ If all of the population growth in the Southeast England since 1951 had been continuous and at the same densities, rather than outside the green belt, the urban footprint would have expanded, on average, less than 8 kilometers. This would have consumed only one-quarter of the green belt area. See: http://www.demographia.com/db-longrbelt.htm.
} 
1. Acceptability: Policies must be acceptable to people to be sustainable.

2. Economics: Policies must not retard economic growth or affluence.

3. Investments: Transport infrastructure must be cost effective and not compromise meeting the needs of others in the urban area by spending more than necessary on individual projects.

\section{TOWARDS THE FUTURE}

Present urban planning and urban transport policies have virtually no hope of materially reducing the share of travel by automobiles at the level of the urban area. Their failure is in not meeting "the needs of the present," which renders them unsustainable. Even more concerning is the fact that they can be destructive, by virtue of their potential to undermine modern standards of living, especially through lower levels of home ownership and diminished mobility throughout the urban area.

Urban planning and urban transport planning will be successful only if its strategies are acceptable to the people who must live within their constraints. The discussion above leads to a conclusion that the role of urban planning should become more modest. Attempts to "engineer" behavior on the part of the citizenry are likely to fail and can lead to resource consuming and counterproductive distortions. Instead, it is suggested that urban planning should generally abandon its prescriptive approach, if for no other reason than is hopeless. Urban planning should instead seek to facilitate the desires of people. This concept is illustrated in Figure $\$ \$ \$$--planners wanted people to walk to the Evry, France RER station one way, but the people chose their own way and have "beaten" their own path. 


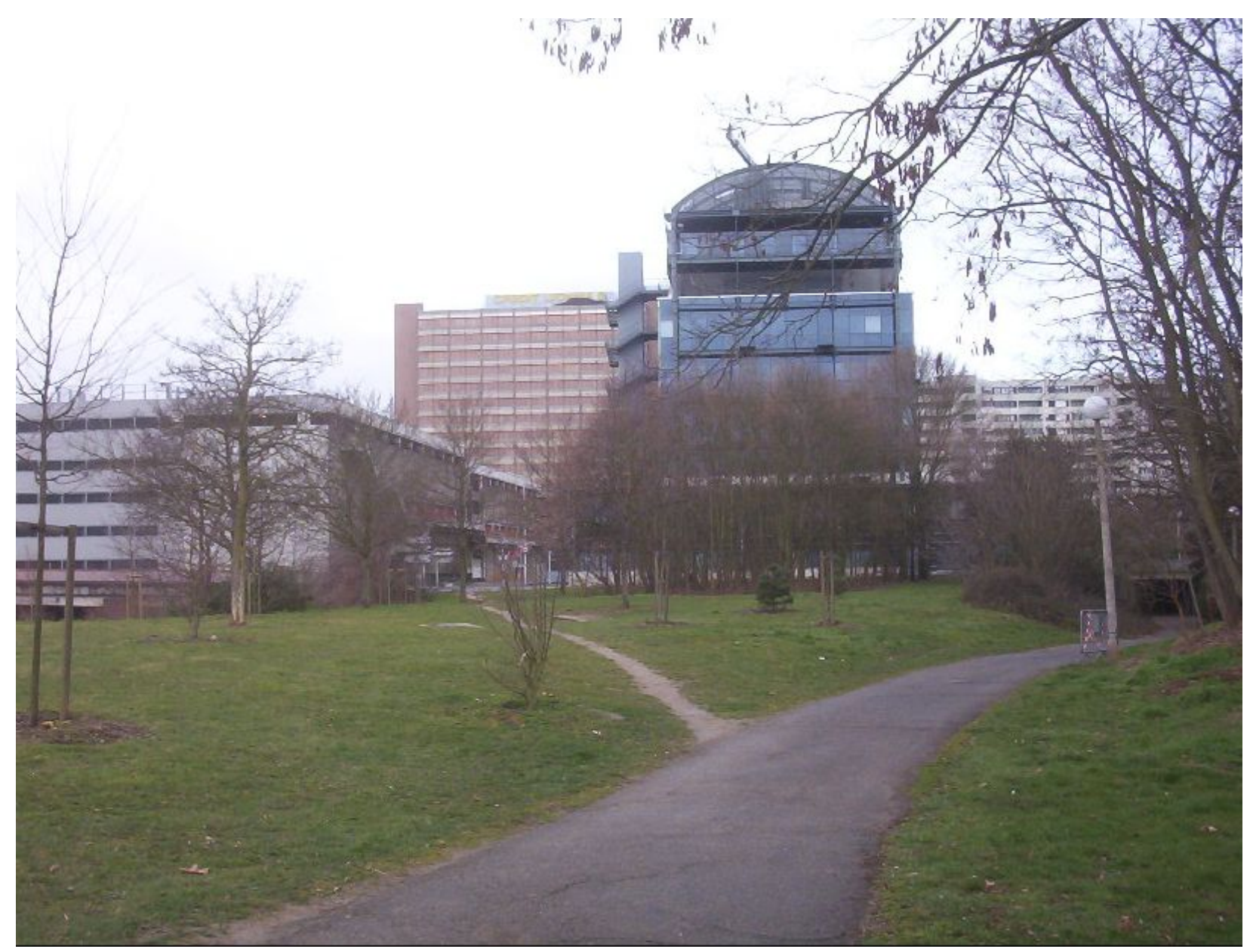

Figure 2

Urban and transport planning are likely to be successful only if they ensure sufficient transport capacity to meet peoples preferences for travel throughout the urban area and if they ensure that there is sufficient land for development, so that home ownership maximized and economic growth induced.

Research Needs: The ultimate question, of course, is whether it is possible, under the circumstances, to have sustainable transport and land use policies. Part of the problem is that much of the purported sustainability problem is in dispute. There is considerable evidence, as noted above, to suggest that land for urban development is not in short supply, that less compact cities do not have greater traffic congestion and that public transport cannot be affordably provided in the greater part of the urban area constituted by the suburbs. This suggests the need for objective reassessment of the problem. There is also a need for broader research with respect to the relationship between mobility, economic growth and household affluence. 


\section{REFERENCES}

Barker, Kate (2004). Review of Housing Supply: Delivering Stability: Securing Our Future Housing Needs: Final Report-Recommendations. Norwich, England: Her Majesty's Stationery Office. http://www.hmtreasury.gov.uk/consultations_and_legislation/barker/consult_barker_index.cfm, accessed March 8, 2005.

Bedsworth, Louise Wells (2004), Climate Control: Global Warming Solutions for California Cars. San Francisco, CA: Union of Concerned Scientists.

Robert W. Burchell, et al, Costs of Sprawl—2000, Transportation Research Board, 2002.

Center for Economics and Business Research, Ltd and Observatoire de l'Economie et des Instiutuions Locales University of Paris XII (1997), Two Great Cities: A Comparison of the Economics of London and Paris.

Cox, Wendell (March 2002). “The Illusion of Transit Choice,” Veritas. San Antonio, TX: Texas Public Policy Foundation. http://www.demographia.com/illusion.pdf.

Demographia,(2004). High-Income World Metropolitan Areas: Core \& Central City Population Trends, http://www.demographia.com/db-highmetro.htm.

Demographia (2005a), Urban Area Historical Densities, http://www.demographia.com/db-4uzahist-e.pdf.

Demographia (2005b), World Urban Population Density by Country and Area, http://www.demographia.com/db-intlua-area2000.htm.

Demographia (2005c), World Urban Areas, http://www.demographia.com/db-worldua.pdf.

Demographia (2005d), International Housing Affordability Ratings and Rankings, http://www.demographia.com/dhi-rank200502.htm.

European Commission, Directorate-General (2003), European Union: Energy and Transport in Figures 2003.

Fouchier V. \& S. Michelon 1999. "Isochrones autour des villes nouvelles aux heures de pointe.” DREIF \& Groupe Central des Villes Nouvelles.

Gerondeau, Christian, 2004. SNCF, transports publics et autres: Les daneuses de la république.

Glaeser, Edward L. and Joseph Gyourko (2002). The Impact of Zoning on Housing Affordability, Cambridge, MA: Harvard Institute of Economic Research.

Hall, Peter (1998), Cities in Civilization. New York: NY: Pantheon Books 
Japan Land Information Division / Land and Water Bureau, Ministry of Land, Infrastructure and Transport, http://tochi.mlit.go.jp/h14hakusho/setsu_1-2-1_eng.html, accessed March 2, 2005.

Kenworthy, Jeffrey, Felix B. Laube and Peter Newman (1999). An International Sourcebook of Automobile Dependence in Cities, 1960-1990. Boulder CO: University of Colorado Press.

Maddison, Angus (2003). The World Economy: Historical Statistics, Paris: Organization for Economic Cooperation and Development.

Nelson, Arthur C., Rolf Pendall, Casey J. Dawkins and Gerrit J. Knaap (2002), The Link Between Growth Management and Housing Affordability: The Academic Evidence, Washington: The Brookings Institution Center on Urban and Metropolitan Policy.

Prud'homme, Remy and Chang-Woon Lee (1998), "Size, Sprawl, Speed and the Efficiency of Cities,” Paris, France: Obervatoire de l’Économic et des Institutions Locals.

Prud'homme, Remy, Richard Darbara, David Newbury, Achim Diekman and Bert Elbeck (1999). Is Our Presnet Transport System Sustainable? Paris: Presses de L’ecole National Pontes et Chaussees.

Public Purpose (2004), Public Transport Market Share Trends: International Urban Areas From 1980, http://www.publicpurpose.com/ut-intlmkt95.htm.

Schwartz, Joel (2003). No Way Back: Why Air Pollution Will Continue to Decline, Washington, DC: AEI Press, 2003, pp. 19 \& 21.

Sieverts, Thomas (2003), Cities Without Cities: An Interpretation of the Zwischenstadt. London, UK: Spon Press.

United States Department of Housing and Urban Development (2005). Why Not in Our Backyard: Removing Barriers to Affordable Housing: An Update to the Report of the Advisory Commission on Regulatory Barriers to Affordable Housing. 